\title{
Facial paralysis due to Ramsay Hunt syndrome - A rare condition
}

\author{
Aline lariessy Campos Paiva ${ }^{1 *}$, João luiz Vitorino Araujo², Vinicius Ricieri Ferraz ${ }^{1}$, José Carlos Esteves Veiga ${ }^{3}$ \\ ${ }^{1}$ Neurosurgery Resident, Faculdade de Ciências Médicas da Santa Casa de São Paulo (FCMSCSP), São Paulo, SP, Brazil \\ ${ }^{2}$ PhD in Neurology from Universidade de São Paulo. Assistant Neurosurgeon, FCMSCSP. Neurosurgeon, Instituto do Câncer Arnaldo Vieira de Carvalho, São Paulo, SP, Brazil \\ ${ }^{3}$ Full Professor and Head of the Neurosurgery Division, FCMSCSP, São Paulo, SP, Brazl
}

\begin{abstract}
SUMMARY
Study conducted at Faculdade de Ciências Médicas da Santa Casa de São Paulo, São Paulo, SP, Brazil

Article received: $7 / 12 / 2016$ Accepted for publication: 10/4/2016

*Correspondence:

Faculdade de Ciências Médicas da Santa Casa de São Paulo Address: Rua Cesário Mota Júnior, 112 São Paulo, SP - Brazil Postal code: 01221-020

Ramsay Hunt syndrome (or herpes zoster oticus) is a rare complication of herpes zoster in which reactivation of latent varicella zoster virus infection in the geniculate ganglion occurs. Usually, there are auricular vesicles and symptoms and signs such otalgia and peripheral facial paralysis. In addition, rarely, a rash around the mouth can be seen. Immunodeficient patients are more susceptible to this condition. Diagnosis is essentially based on symptoms. We report the case of a diabetic female patient who sought the emergency department with a complaint of this rare entity.
\end{abstract} lariessy@hotmail.com

http://dx.doi.org/10.1590/1806-9282.63.04.301
Keywords: facial paralysis, herpes zoster oticus.
A 68 year-old female patient with history of type II diabetes sought our emergency service (ER) with a clinical complaint of difficulty to blink and left-sided hearing loss associated with labial deviation to the right. The symptoms had begun eleven days before her admission. On neurological examination, we noted left facial paralysis House-Brackman grade IV associated with vesicles and crusted lesions on the left auricle (Figure 1). She complained of hearing loss on the same side. No other abnormalities were found in the general examination.
This clinical picture is therefore very suggestive of a rare condition known as Ramsay Hunt syndrome (herpes zoster oticus). It was first described by James Ramsay Hunt in $1907^{1,2}$ and its occurrence is due to varicella zoster virus (VZV) reactivation in sensory root ganglia. The geniculate ganglion is located on the facial nerve in the depths of the internal auditory meatus at the entrance to the bony fallopian canal. ${ }^{3}$ The infection involves facial and vestibulocochlear nerves, causing peripheral facial paralysis, otalgia and sensorineural hearing loss. Vestibular symptoms are rare. ${ }^{2}$

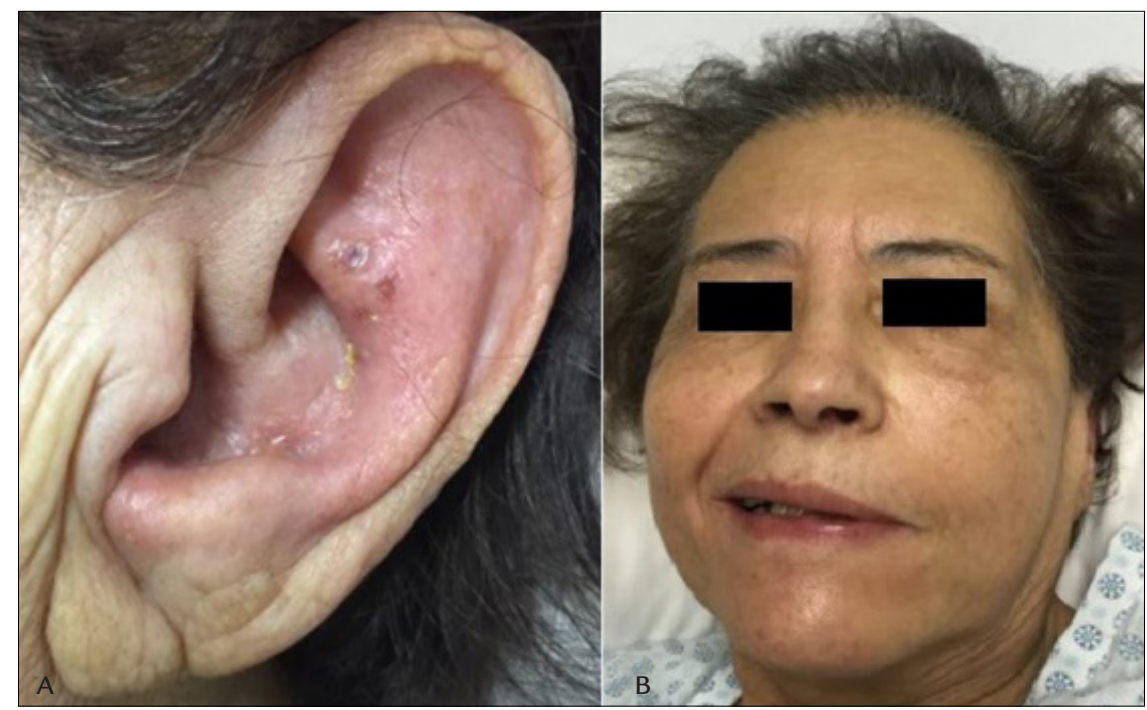

FIGURE 1 A. Auricular vesicles at the left pinna. B. Left peripheral facial paralysis House-Brackman IV, $149 \times 91$ mm (96 x 96 DPI). 
Diagnosis is performed based on signs and symptoms. Examination of cerebrospinal fluid and gadolinium-enhanced MRIs have proved no diagnostic or prognostic value, ${ }^{4}$ although a positive polymerase chain reaction (PCR) test for VZV is used for confirmation. ${ }^{5}$ Proper physical examination and history is essential because in many cases, when facial paralysis is noted at the ER, the first hypothesis is that of stroke, which leads to misdiagnosis and wrong treatment and can cause sequelae, such as permanent hearing loss.

After diagnosis, the treatment includes steroids and antiviral drugs during the acute fase. ${ }^{4,5}$ Usually, prednisone (duration and dose varies a lot but usually is $1 \mathrm{mg} / \mathrm{kg} / \mathrm{day}$ for 5-7 day) is combined with intravenous or oral acyclovir (or similar drugs) concomitantly. It is essential to refer patients to rehabilitation after the acute phase for motor physiotherapy, biofeedback and massage therapy., ${ }^{2,4}$ Our patient received seven days of prednisone and acyclovir, and a request for physioterapy as soon as the pain improved. She progressed with complete resolution of the facial paralysis 30 days after onset of treatment and no hearing sequelae was observed.

\section{Resumo}

Paralisia facial secundária à síndrome de Ramsay Hunt Uma condição rara
A síndrome de Ramsay Hunt (ou zóster auricular) é uma complicação rara do herpes-zóster em que ocorre reativação de uma infecção latente pelo vírus varicela-zóster no gânglio geniculado. Geralmente, estão presentes vesículas auriculares e sintomas como otalgia e paralisia facial periférica. Além disso, mais raramente pode haver rash ao redor da boca. Pacientes com imunodeficiência apresentam maior susceptibilidade para essa condição. O diagnóstico é essencialmente pelo quadro clínico. É apresentado o caso de uma paciente diabética que compareceu ao setor de emergência com essa manifestação rara.

Palavras-chave: paralisia facial, herpes-zóster da orelha externa.

\section{References}

1. Hunt JR. On herpetic inflammations of the geniculate ganglion. A new syndrome and its complications. J Nerv Ment Dis. 1907; 34(2):73-96.

2. Gondivkar S, Parikh V, Parikh R. Herpes zoster oticus: a rare clinical entity. Contemp Clin Dent. 2010; 1(2):127-9.

3. Simpson RR. Section of Otology - Discussion: the Ramsay Hunt syndrome. Proc Royal Soc Med. 1953; 47:371-84.

4. Sweeney CJ, Gilden DH. Ramsay Hunt syndrome. J Neurol Neurosurg Psychiatry. 2001; 71(2):149-54.

5. Costa A, Veiga A. Ramsay-Hunt syndrome in the differential diagnosis of stroke. Rev Soc Bras Med Trop. 2013; 46(5):663. 